Research article

\title{
A review of randomized controlled trials comparing the effectiveness of hand held computers with paper methods for data collection

\author{
Shannon J Lane ${ }^{1}$, Nancy M Heddle ${ }^{1,2}$, Emmy Arnold ${ }^{1}$ and Irwin Walker*1
}

Address: ${ }^{1}$ Department of Medicine, McMaster University, Hamilton, Canada and ${ }^{2}$ Canadian Blood Services, Hamilton, Canada

Email: Shannon J Lane - shewhofeels@hotmail.com; Nancy M Heddle - heddlen@mcmaster.ca; Emmy Arnold - arnolde@mcmaster.ca; Irwin Walker* - walkeri@mcmaster.ca

* Corresponding author

Published: 31 May 2006

BMC Medical Informatics and Decision Making 2006, 6:23 doi:10.1 186/1472-6947-6-23

This article is available from: http://www.biomedcentral.com/l472-6947/6/23

(C) 2006 Lane et al; licensee BioMed Central Ltd.

This is an Open Access article distributed under the terms of the Creative Commons Attribution License (http://creativecommons.org/licenses/by/2.0), which permits unrestricted use, distribution, and reproduction in any medium, provided the original work is properly cited.
Received: 21 June 2005
Accepted: 31 May 2006

\begin{abstract}
Background: Handheld computers are increasingly favoured over paper and pencil methods to capture data in clinical research.

Methods: This study systematically identified and reviewed randomized controlled trials (RCTs) that compared the two methods for self-recording and reporting data, and where at least one of the following outcomes was assessed: data accuracy; timeliness of data capture; and adherence to protocols for data collection.

Results: A comprehensive key word search of NLM Gateway's database yielded 9 studies fitting the criteria for inclusion. Data extraction was performed and checked by two of the authors. None of the studies included all outcomes. The results overall, favor handheld computers over paper and pencil for data collection among study participants but the data are not uniform for the different outcomes. Handheld computers appear superior in timeliness of receipt and data handling (four of four studies) and are preferred by most subjects (three of four studies). On the other hand, only one of the trials adequately compared adherence to instructions for recording and submission of data (handheld computers were superior), and comparisons of accuracy were inconsistent between five studies.
\end{abstract}

Conclusion: Handhelds are an effective alternative to paper and pencil modes of data collection; they are faster and were preferred by most users.

\section{Background}

The use of portable handheld computer technology in the field of health care and clinical research is on the rise, with a corresponding increase in publications. A search of Medline, using the MeSH term "computers, handheld" and text words "handheld computer(s)" combined as "or", revealed a steady increase in the yearly number of publications from none in 1995 to 209 publications in 2003.

The use of handheld computers has been described in a variety of subjects and clinical settings, including: analgesic headache treatments[1]; pain research[2]; bipolar disorder research[3]; asthma research[4,5]; tobacco use research[6]; orthopedic research[7]; urinary incontinence 
research [8,9]; smoking cessation research $[10,11]$; brain injury research $[12,13]$; menstrual symptom research $[14]$; field data collection research[15,16]; diabetes research[17]; eating disorder research [18]; respiratory care research[19]; blood donor research[20]; and adolescent anxiety research[21]. Many of these studies have suggested that handheld technology has several advantages over traditional paper and pencil modes of data capture including but not limited to: data accuracy; timeliness of data capture; and adherence to protocols for data collection.

There are a number of published reviews on the use of handheld computers in the health care setting that focus on design aspects of the handheld device, advantages compared with paper methods, and the clinical applications in which they have been used [22-30]. These reviews provide the reader with much insight but they have limitations when comparing the actual performance of handheld computers with paper methods. Most of the literature is descriptive rather than comparative, focusing on the technology, the methods and/or the experience. When comparing the effectiveness of two methods, descriptive studies have limitations as they lack a comparative control group, and they are prone to publication bias and subject selection bias [31].

Despite the proliferation of literature describing the applications of handheld computers, the number of evidence based publications addressing the efficacy of this technology compared with the traditional method remains few. The purpose of this manuscript is to summarize the literature on randomized controlled trials focusing on the use of handheld computers compared to traditional paper and pencil methods, where at least one of the following outcomes was assessed: data accuracy; timeliness; adherence to protocols; and/or patient preference.

\section{Methods}

\section{Literature search}

NLM Gateway, a single interface that searches in "multiple retrieval systems", including MEDLINE ${ }^{\circledast} /$ PubMed $^{\circledast}$, was searched using the following text words, both separately, and combined with "OR": "palm top computer," "PDA," "personal digital assistant," "pocket computer," "electronic diary," "diary keeping," "diary keeping methods," "electronic forms and data collection," "microcomputer," "palm pilot," "handheld computer," and the MeSH headings "data collection/*instrumentation" and "computers, handheld". The search was performed during the period May 1st 2003 until June, 2005 and was restricted to publications in English. Two reviewers independently reviewed the citations and abstracts of all articles retrieved from the search (I.W. and S.L.) according to the inclusion criteria. Studies that met the following inclusion criteria were included in this review: study design was a rand- omized controlled trial (RCT); the study compared the use of handheld computer to paper and pencil as data collection devices; and at least one of the following outcomes was assessed - user preference, data accuracy, adherence, and timeliness. All potentially relevant articles were retrieved and reviewed. The bibliographies and reference lists of these documents were reviewed by one researcher (S.L.) to identify other potentially relevant articles that fit the inclusion criteria. Two reviewers independently classified the potentially relevant articles and then met to discuss discrepancies in classification. Articles in disagreement were discussed using consensus until both reviewers agreed upon the classifications. Data were extracted from each of the eligible studies by one of the authors (SL), under the following headings: study purpose; study design; duration of follow up; location; patient population; number of subjects; instrument and mode of entry; and outcome measures. Duration of follow up was considered important because preferences for new technologies might conceivably lack durability, initial enthusiasm and 'halo' effects clouding other issues of acceptability. The accuracy of the data extracted was confirmed by two of the authors (IW, and NH).

\section{Results}

There were a total of 201 potentially relevant studies identified by the search strategy. After a review of the titles and abstracts 141 articles were retrieved of which 9 met the inclusion criterion for review in this study [32-40]. Table 1 provides a summary of the information extracted from each of the eligible RCTs included in this review.

Topics addressed by the nine randomized studies were: Symptoms in patients with overactive bladder[33], appreciation of pain by volunteers[34], collection of chart data by medical students[35], symptoms of patients in an orthopedic clinic[36], rating of appetite by volunteers[37], respiratory data in patients with lung diseases[38], quality of life in patients with gastrointestinal disease[39], food intake by patients with diabetes [40] and factor concentrate use by patients with hemophilia[32]. Three of the studies used a parallel RCT design[32,36,39]; whereas, the remaining studies used a randomized crossover design[33-35,37,38,40]. The duration of the followup in the studies varied in length but in all cases would be considered short term i.e. same-day experiments[34,36], follow up lasting two to three days $[35,37,39]$; follow up over a one week period [33]; and two other studies where follow-up lasted one month per arm [38,40]. One study was carried out over six months[32]. In five of the studies the data collection occurred at the patient's residence $[32,33,37,38,40]$, while the other four studies were conducted at institutions (i.e.: clinic, physician's office, hospital) [34-36,39]. 
Table I: Summary of randomized controlled trials comparing handheld computers to paper and pen.

\begin{tabular}{|c|c|c|c|c|c|c|c|c|}
\hline Study & Purpose & Design & $\begin{array}{l}\text { Duration of } \\
\text { Follow Up }\end{array}$ & Location & $\begin{array}{c}\text { Patient } \\
\text { Population }\end{array}$ & $\begin{array}{l}\text { Number of } \\
\text { Subjects }\end{array}$ & $\begin{array}{c}\text { Instrument } \\
\text { and Mode of } \\
\text { Entry }\end{array}$ & $\begin{array}{l}\text { Outcome } \\
\text { Measures }\end{array}$ \\
\hline $\begin{array}{l}\text { Quinn P et al. } \\
200333\end{array}$ & $\begin{array}{l}\text { To assess the } \\
\text { effectiveness } \\
\text { of a portable } \\
\text { electronic } \\
\text { diary as a data } \\
\text { collection } \\
\text { device for } \\
\text { symptoms of } \\
\text { an overactive } \\
\text { bladder } \\
\text { (OAB) }\end{array}$ & $\begin{array}{l}\text { Randomized } \\
\text { crossover } \\
\text { study }\end{array}$ & $\begin{array}{l}7 \text { days/arm, } \\
\text { I } 4 \text { days total. }\end{array}$ & $\begin{array}{l}\text { Patient's } \\
\text { residence }\end{array}$ & $\begin{array}{l}\text { Patients with } \\
\text { a diagnosis of } \\
\text { over-active } \\
\text { bladder. }\end{array}$ & $\begin{array}{l}35 \text { patients } \\
\text { were } \\
\text { recruited, } 2 \\
\text { were } \\
\text { excluded post } \\
\text { randomizatio } \\
\text { n. }\end{array}$ & $\begin{array}{l}\text { Intervention: } \\
\text { - Customized } \\
\text { version of } \\
\text { MiniDoc } \\
\text { - Daily diary } \\
\text { - Visual } \\
\text { Analogue } \\
\text { Scale (VAS) } \\
\text { Control: } \\
\text { - Paper diary } \\
\text { - Visual } \\
\text { Analogue } \\
\text { Scale (VAS) }\end{array}$ & $\begin{array}{l}\text { Effectiveness } \\
\text { of the } \\
\text { electronic } \\
\text { diary } \\
\text { Acceptability } \\
\text { to patients }\end{array}$ \\
\hline $\begin{array}{l}\text { Jamison RN } \\
\text { et al. } 200234\end{array}$ & $\begin{array}{l}\text { To compare } \\
\text { the e-VAS } \\
\text { (electronic) } \\
\text { with p-VAS } \\
\text { (paper) for } \\
\text { cognitive and } \\
\text { sensory } \\
\text { stimuli. }\end{array}$ & $\begin{array}{l}\text { Single centre } \\
\text { randomized } \\
\text { crossover } \\
\text { study }\end{array}$ & $\begin{array}{l}\text { Data } \\
\text { collected in a } \\
\text { I hour } \\
\text { session }\end{array}$ & Institution & $\begin{array}{l}\text { Healthy } \\
\text { volunteers }\end{array}$ & 24 subjects & $\begin{array}{l}\text { Intervention: } \\
\text { - Palm Pilot } \\
\text { Illxe } \\
\text { - Visual } \\
\text { Analogue } \\
\text { Scale (VAS) } \\
\text { Control: } \\
\text { - Paper Visual } \\
\text { Analogue } \\
\text { Scale (VAS) }\end{array}$ & $\begin{array}{l}\text { Validity and } \\
\text { equivalence of } \\
\text { methods }\end{array}$ \\
\hline $\begin{array}{l}\text { Lal SO et al. } \\
2000^{35}\end{array}$ & $\begin{array}{l}\text { To determine } \\
\text { whether } \\
\text { electronic } \\
\text { data } \\
\text { collection and } \\
\text { downloading } \\
\text { to a personal } \\
\text { computer } \\
\text { spreadsheet is } \\
\text { faster and } \\
\text { more } \\
\text { accurate than } \\
\text { written data. }\end{array}$ & $\begin{array}{l}\text { Randomized } \\
\text { crossover } \\
\text { design }\end{array}$ & $\begin{array}{l}\text { Chart data } \\
\text { collected } \\
\text { within a } 96 \\
\text { hour window } \\
\text { period }\end{array}$ & $\begin{array}{l}\text { Shriners } \\
\text { Burns } \\
\text { Hospital }\end{array}$ & $\begin{array}{l}\text { Medical } \\
\text { student } \\
\text { volunteering } \\
\text { for data } \\
\text { collection }\end{array}$ & $\begin{array}{l}3 \text { medical } \\
\text { students } \\
\text { retrieving } \\
\text { data from I } 10 \\
\text { medical } \\
\text { charts }\end{array}$ & $\begin{array}{l}\text { Intervention: } \\
\text { - 3Com Palm } \\
\text { Illx } \\
\text { - Data entry } \\
\text { into an Excel } \\
\text { spreadsheet } \\
\text { Control: } \\
\text { - Paper } \\
\text { duplicate of } \\
\text { Excel } \\
\text { spreadsheet. }\end{array}$ & $\begin{array}{l}\text { Speed/Time } \\
\text { Accuracy as } \\
\text { measured by } \\
\text { error } \\
\text { incidence }\end{array}$ \\
\hline $\begin{array}{l}\text { McBride JS et } \\
\text { al. } 199936\end{array}$ & $\begin{array}{l}\text { To examine } \\
\text { how data can } \\
\text { be collected } \\
\text { at point of } \\
\text { care. } \\
\text { Comparison } \\
\text { of electronic } \\
\text { and paper } \\
\text { versions of a } \\
\text { standard } \\
\text { quality survey. }\end{array}$ & $\begin{array}{l}\text { Randomized } \\
\text { design }\end{array}$ & $\begin{array}{l}\text { Data } \\
\text { collected in } \\
\text { one session }\end{array}$ & $\begin{array}{l}\text { Wake Forest } \\
\text { PhysiciansOrt } \\
\text { hopedics } \\
\text { Department } \\
\text { Clinics }\end{array}$ & $\begin{array}{l}\text { Patients } \\
\text { visiting an } \\
\text { orthopedic } \\
\text { clinic }\end{array}$ & 349 patients & $\begin{array}{l}\text { Intervention: } \\
\text { - Mini Doc, a } \\
\text { portable } \\
\text { electronic } \\
\text { data capturing } \\
\text { device. } \\
\text { Control: } \\
\text { - Paper and } \\
\text { pencil survey } \\
\text { form }\end{array}$ & $\begin{array}{l}\text { Accuracy } \\
\text { Acceptibility } \\
\text { to patients } \\
\text { Internal } \\
\text { consistency } \\
\text { reliability }\end{array}$ \\
\hline $\begin{array}{l}\text { Stratton RJ et } \\
\text { al. } 199837\end{array}$ & $\begin{array}{l}\text { To assess an } \\
\text { electronic } \\
\text { visual } \\
\text { analogue scale } \\
\text { with a paper } \\
\text { method for } \\
\text { appetite } \\
\text { rating To } \\
\text { examine test- } \\
\text { retest } \\
\text { reliability. }\end{array}$ & $\begin{array}{l}\text { Randomized } \\
\text { crossover } \\
\text { study design }\end{array}$ & $\begin{array}{l}4 \text { day study } \\
\text { Test-retest } \\
\text { over } 2 \\
\text { additional } \\
\text { days }\end{array}$ & $\begin{array}{l}\text { Subject's } \\
\text { residence }\end{array}$ & $\begin{array}{l}\text { Healthy free- } \\
\text { living } \\
\text { volunteers }\end{array}$ & $\begin{array}{l}\text { I } 2 \text { volunteers } \\
\text { participated in } \\
\text { comparison } \\
\text { study, I } 3 \\
\text { participated in } \\
\text { preference } \\
\text { study }\end{array}$ & $\begin{array}{l}\text { Intervention: } \\
\text { - Apple } \\
\text { Newton } \\
\text { Message Pad } \\
\text { - visual } \\
\text { analogue scale } \\
\text { questionnaire } \\
\text { Control: } \\
\text { - Paper and } \\
\text { pencil } \\
\text { - visual } \\
\text { analogue scale } \\
\text { questionnaire }\end{array}$ & $\begin{array}{l}\text { Comparability } \\
\text { of methods } \\
\text { (Equivalence) } \\
\text { Patient } \\
\text { preferences }\end{array}$ \\
\hline
\end{tabular}


Table I: Summary of randomized controlled trials comparing handheld computers to paper and pen. (Continued)

\begin{tabular}{|c|c|c|c|c|c|c|c|c|}
\hline $\begin{array}{l}\text { Tiplady B et } \\
\text { al. 1997 } \\
\text { (study I) } 38\end{array}$ & $\begin{array}{l}\text { To assess the } \\
\text { suitability of } \\
\text { PDAs } \\
\text { compared to } \\
\text { paper diaries, } \\
\text { for daily } \\
\text { collection of } \\
\text { data on lung } \\
\text { function. }\end{array}$ & $\begin{array}{l}\text { Randomized } \\
\text { two period } \\
\text { crossover } \\
\text { design }\end{array}$ & I month/arm & $\begin{array}{l}\text { Patient's } \\
\text { residence }\end{array}$ & $\begin{array}{l}\text { Out-patients } \\
\text { with chronic } \\
\text { obstructive } \\
\text { airways } \\
\text { disease }\end{array}$ & 22 patients & $\begin{array}{l}\text { Intervention: } \\
\text { - Apple } \\
\text { Message Pad } \\
\text { - Daily diary } \\
\text { Control: } \\
\text { - Paper and } \\
\text { pencil } \\
\text { - Daily diary }\end{array}$ & $\begin{array}{l}\text { Comparability } \\
\text { of methods, } \\
\text { re: data } \\
\text { quality } \\
\text { (missing and } \\
\text { problematic } \\
\text { data) }\end{array}$ \\
\hline $\begin{array}{l}\text { Tiplady B et } \\
\text { al. 1997 } \\
\text { (study 2) } 38\end{array}$ & $\begin{array}{l}\text { To assess the } \\
\text { suitability of } \\
\text { electronic } \\
\text { diary for } \\
\text { home use, } \\
\text { transmitting } \\
\text { respirology } \\
\text { data. }\end{array}$ & $\begin{array}{l}\text { Observational } \\
\text { study }\end{array}$ & $\begin{array}{l}\text { Completed } \\
\text { electronic } \\
\text { diary for I } \\
\text { month }\end{array}$ & $\begin{array}{l}\text { Patient's } \\
\text { residence }\end{array}$ & $\begin{array}{l}\text { Patients with } \\
\text { chronic } \\
\text { airways } \\
\text { disease. }\end{array}$ & 37 patients & $\begin{array}{l}\text { Intervention: } \\
\text { - Apple } \\
\text { Message Pad. } \\
\text { - Daily diary }\end{array}$ & $\begin{array}{l}\text { Patient } \\
\text { preferences } \\
\text { Ease of use }\end{array}$ \\
\hline $\begin{array}{l}\text { Drummond } \\
\text { HE et al. } 1995 \\
39\end{array}$ & $\begin{array}{l}\text { To compare } \\
\text { the responses } \\
\text { obtained from } \\
\text { a quality of } \\
\text { life (QOL) } \\
\text { questionnaire } \\
\text { s using } \\
\text { electronic } \\
\text { (PDA) and } \\
\text { conventional } \\
\text { (paper). }\end{array}$ & $\begin{array}{l}\text { Randomized, } \\
\text { open, two } \\
\text { period } \\
\text { crossover }\end{array}$ & $\begin{array}{l}3 \text { office visits; } \\
\text { I for training, } \\
\text { I to complete } \\
\text { each arm. }\end{array}$ & Institution & $\begin{array}{l}\text { Patients } \\
\text { attending a } \\
\text { gastrointestin } \\
\text { al clinic as } \\
\text { outpatients }\end{array}$ & 46 patients & $\begin{array}{l}\text { Intervention: } \\
\text { - Apple } \\
\text { Newton } \\
\text { Message Pad. } \\
\text { - Quality of } \\
\text { Life } \\
\text { questionnaire } \\
\text { (QOL) } \\
\text { Control: } \\
\text { - Paper and } \\
\text { pencil }\end{array}$ & $\begin{array}{l}\text { Comparability } \\
\text { of methods, } \\
\text { looking at } \\
\text { missing and } \\
\text { problematic } \\
\text { data } \\
\text { Patient } \\
\text { preferences }\end{array}$ \\
\hline $\begin{array}{l}\text { Rivellesse AA } \\
\text { et al. 1991 } 40\end{array}$ & $\begin{array}{l}\text { To evaluate } \\
\text { an electronic } \\
\text { (Food-Meter) } \\
\text { method for } \\
\text { recording 7- } \\
\text { day food } \\
\text { intake. }\end{array}$ & $\begin{array}{l}\text { Randomized } \\
\text { cross-over } \\
\text { design } \\
\text { repeated } \\
\text { once. }\end{array}$ & 4 weeks & $\begin{array}{l}\text { - patient's } \\
\text { residence }\end{array}$ & $\begin{array}{l}\text { Insulin- } \\
\text { dependent } \\
\text { diabetic } \\
\text { patients } \\
\text { (IDDM) }\end{array}$ & 21 & $\begin{array}{l}\text { Intervention: } \\
\text { - "Food- } \\
\text { Meter" (Miles, } \\
\text { Elkhart, IN) } \\
\text { - Daily diary } \\
\text { Control: } \\
\text { - Paper and } \\
\text { pencil } \\
\text { - Daily diary }\end{array}$ & $\begin{array}{l}\text { Agreement } \\
\text { between } \\
\text { methods }\end{array}$ \\
\hline $\begin{array}{l}\text { Walker l et al. } \\
200432\end{array}$ & $\begin{array}{l}\text { To compare } \\
\text { handheld } \\
\text { computers } \\
\text { and paper } \\
\text { diaries for } \\
\text { recording } \\
\text { intravenous } \\
\text { infusions of } \\
\text { hemophilic } \\
\text { clotting factor } \\
\text { concentrates. }\end{array}$ & $\begin{array}{l}\text { Randomized } \\
\text { controlled } \\
\text { trial, parallel } \\
\text { design. }\end{array}$ & 6 months & $\begin{array}{l}\text { - patients' } \\
\text { residence }\end{array}$ & $\begin{array}{l}\text { Patients with } \\
\text { hemophilia }\end{array}$ & 41 & $\begin{array}{l}\text { Intervention: } \\
\text { - Palm III with } \\
\text { bar code } \\
\text { reader } \\
\text { Control: } \\
\text { - Touch- } \\
\text { sensitive } \\
\text { paper diary. }\end{array}$ & $\begin{array}{l}\text { Compliance } \\
\text { Timeliness } \\
\text { Accuracy } \\
\text { Preference }\end{array}$ \\
\hline
\end{tabular}

The electronic forms of data entry were variable, utilizing push button technology[33,36], or touch sensitive screens using a stylus pen [34,37-39]. In one study data were entered via bar codes and an optical reading system[40], while the mode of entry for one study was not clearly specified [35]. In the remaining study [32] data was entered into a handheld computer by a combination of an integrated bar code reader and stylus pen.

Handheld computers and paper and pencil technologies were compared using a variety of applications. In three of the studies subjects were asked to rate some kind of subjective symptom or experience using visual analogue scales (VAS) [33,34,37]; whereas in a study of patients with asthma daily symptoms were recorded using custom software[38]. In two of the studies, questionnaires regarding quality of life [39] and quality of care [36] were administered in paper and electronic forms. Three studies examined the abilities of both devices to record objective data such as burn variables[35], daily food intake [40]and intravenous infusions of hemophilic clotting factor concentrates[32].

In three of the studies healthy volunteers/medical students participated to evaluate the two methods of data collection: electronic using a handheld or paper based manual collection $[34,35,37]$. The remaining six studies involved a variety of patient populations including 
patients with: bladder disorders[33], orthopedic problems[36], chronic obstructive airway disease[38], gastrointestinal problems,[39] diabetes [40] and hemophilia [32]. Summaries of the different studies are given in Table 1.

All, but one of the studies in this review have explored more than one outcome measure[40]. Three studies evaluated the acceptability of handheld computers to patients $[32,33,36]$. In one of these studies acceptability was determined by comparing percentages of positive features reported for each device [36]; the second study measured acceptability using an ease-of-use scale and a face-to-face interview questionnaire to elicit subject's opinions [33]; in the third study [32], acceptability was not assessed but ten $(50 \%)$ of the patients who had used both paper diary and handheld computer methods subsequently took part in a subsequent qualitative study [41]. Three studies looked at the comparability of handheld computers to paper and pencil devices: two of the studies compared missing and problematic data points $[38,39]$; and one study compared results obtained using both paper and electronic visual analogue scales [37]. Two studies explored the equivalence of data obtained by electronic and paper and pencil methods, one used VAS [34], and the other explored differences between group scale scores using the Wilcoxon test [36]. Two studies assessed the validity of electronic modes of data capture: one study attempting to validate an electronic VAS [34]; the other study measuring agreement between conventional and electronic devices in order to validate an innovative device used for data capture pertaining to food intake [40]. The speed and accuracy of both methods were measured in one study [35], as was effectiveness [33] in another. The final study [32] compared adherence to a set schedule for submission of data, accuracy of data, and lag time between data entry in the home and receipt of data at the clinic. Reminder phone calls were made according to a strict protocol.

\section{Data accuracy}

The findings related to an outcome of accuracy are summarized in Table 2. Six out of nine studies [32-36,38]compared data accuracy obtained by handheld technology to that of paper and pencil devices. Measurements of accuracy differed between studies. In two trials $[34,36]$ data

Table 2: Summary of the results of data accuracy assessed in six randomized controlled trials

\begin{tabular}{|c|c|c|c|}
\hline \multirow[t]{2}{*}{ Study } & \multicolumn{2}{|c|}{ Results related to data Accuracy } & \multirow[t]{2}{*}{ Definitions } \\
\hline & Hand Held Computers & Paper & \\
\hline Tiplady B et al. 199738 & $\begin{array}{l}\text { Missing data } 8.91 \% \\
\text { Problematic data** 5.64\% }\end{array}$ & $\begin{array}{l}\text { Missing data } 0.16 \% \\
\text { Problematic data** } 0.24 \%\end{array}$ & $\begin{array}{l}\text { Accuracy was defined by } \\
\text { comparing missing and problematic } \\
\text { data between the two methods. } \\
\text { **Problematic data points defined } \\
\text { as those requiring some } \\
\text { intervention or editing. }\end{array}$ \\
\hline McBride JS et al. 199936 & $\begin{array}{l}\text { No difference in missing item } \\
\text { responses between PDA and } \\
\text { paper in } 4 / 5^{*} \text { subscales, }(p<0.05) \text {. }\end{array}$ & $\begin{array}{l}\text { No differences in missing item } \\
\text { responses between PDA and } \\
\text { paper in } 4 / 5^{*} \text { subscales, }(p<0.05) \text {. }\end{array}$ & $\begin{array}{l}\text { Defined as a comparison of missing } \\
\text { item responses between the two } \\
\text { methods. }\end{array}$ \\
\hline Lal SO et al. 200035 & $2.8 \%$ error frequency. & $6.7 \%$ error frequency & $\begin{array}{l}\text { Data fields analyzed for frequency } \\
\text { of error were gender, race, date of } \\
\text { birth, date of burn, date of } \\
\text { admittance to hospital, and burn } \\
\text { type. Accuracy determined by } \\
\text { comparing these fields with } \\
\text { original medical record. }\end{array}$ \\
\hline Jamison RN et al. 200234 & \multicolumn{2}{|c|}{$\begin{array}{l}\text { Of } 503 \text { paired verbal stimuli in } 24 \text { subjects the correlation between } \\
\text { paper and PDA ratings was } r=.97 \text { (range } 0.95-0.98 \text { ), for sensory stimuli } \\
r=0.86 \text { (range } 0.81-0.92 \text { ). Correlation between group electronic VAS } \\
\text { and paper VAS ratings to common verbal stimuli } r^{2}=0.997 \text {, for the } \\
\text { common sensory stimuli group correlation was } r^{2}=0.99 \text {. }\end{array}$} & $\begin{array}{l}\text { Defined as the degree of } \\
\text { correlation between the two } \\
\text { methods of rating. }\end{array}$ \\
\hline Quinn P et al. 200333 & $\begin{array}{l}\text { Errors not possible in electronic } \\
\text { diaries due to prompt and format } \\
\text { of questions and responses. }\end{array}$ & $\begin{array}{l}\text { Errors "detected" in } 80 \% \text { of paper } \\
\text { diaries }\end{array}$ & $\begin{array}{l}\text { Errors defined as incomplete } \\
\text { times, inconsistent timing of } \\
\text { events, incomplete events, } \\
\text { incorrect completion of VAS. }\end{array}$ \\
\hline Walker I et al. 200432 & $\begin{array}{l}3 \text { vials/patient not accounted for. } \\
15 \text { patients with errors. }\end{array}$ & $\begin{array}{l}5 \text { vials/patient not accounted for }(P \\
=0.45) . \\
\text { I3 patients with errors }(P=1.00) \text {. }\end{array}$ & $\begin{array}{l}\text { Both the number of vials/patient } \\
\text { not accounted for in each group } \\
\text { and the number of patients in each } \\
\text { group with errors. }\end{array}$ \\
\hline
\end{tabular}

*The subscale in which differences in missing item responses were found was the Ist response choice on PDA, authors suggest this could be attributed to learning effect. 
accuracy was measured by comparing the equivalence of responses obtained using both paper and pencil and hand-held microcomputer data collection modes. The authors found a similar degree of accuracy between results recorded on a paper and pencil visual analogue scale and VAS administered via a handheld microcomputer. Similarly, a comparison of paper and pencil and handheld microcomputer versions of the PRESS, GANEY ${ }^{\mathrm{TM}}$ outpatient survey questionnaire determined that both modes of data capture produced comparable results. In two other studies, data quality/accuracy were measured by comparing the percentages of errors obtained by each device $[33,35]$. Both studies found that data collected electronically were more accurate and contained fewer errors than data captured manually with paper and pencil. In one case, the paper and pencil mode of data collection produced a $6.7 \%$ error frequency, compared with a significantly lower $2.8 \%$ error frequency obtained by patients using the microcomputer technology [35]. The other study [32] detected errors in $80 \%$ of the paper diary data, but found the error rates of electronic diaries to be low, hypothesizing that the prompts and structures of questions and responses guide the user towards greater accuracy. Another study [38] measured data accuracy by comparing the proportions of 'missed' and/or 'problematic data' points between the two methods; detecting a higher proportion of missing and/or problematic data in the PDA diaries. The final study [32] compared the number of medication vials unaccounted for and also the proportion of individuals having errors in the number of vials not accounted for; the error rate was similar for the two methods.

\section{Timeliness}

Table 3 provides a summary of findings related to the timeliness of data collection. Four out of the nine RCTs report outcomes comparing the timeliness of electronic

portable microcomputer technology to paper and pencil data collection devices $[32,35,38,40]$. One of the three trials [35] directly measured data entry time between electronic and paper and pencil devices. In this study [32] the use of electronic instruments reduced data entry and transfer time by $23 \%$. A second study [32] compared the interval between the times of intravenous infusions and the receipt of data; the interval from those using handheld computers was greatly reduced $(0.25$ vs. 25 days, p < $0.0001)$. The remaining two studies $[38,40]$ reported that electronic instruments reduced the time required for data handling and transfer but did not provide time estimates.

\section{Adherence}

Three of the nine studies addressed the issue of adherence $[32,33,38]$ but only one provided objective data [32]. In this latter study a schedule for submission of data was provided prospectively to the patients; adherence by users of handheld computers was $86 \%$ versus $48 \%$ for paper diary users $(\mathrm{P}<0.0001)$ despite an increased number of reminder phone calls to users of paper diaries compared to the users of handheld computers ( 5 versus $1, \mathrm{P}<$ $0.0001)$. Neither of the other two studies $[33,38]$ made direct measurements of adherence between electronic and paper/pencil modes of data collection. In one trial [33] adherence was evaluated for electronic data capture but not for paper and pencil data collection. In the same study where patients were instructed to complete diaries daily, recording events as soon as possible after occurrence, $73 \%$ of the cases entered data into the diaries within two hours of the event occurring. In one study, where adherence was not measured [38] the authors report unconfirmed suspicions of retrospective data entry in paper diaries, which relates specifically to the issue of adherence.

Table 3: Summary of the findings related to timelines in the four studies reporting this outcome.

\begin{tabular}{|c|c|c|c|}
\hline \multirow[t]{2}{*}{ Study } & \multicolumn{2}{|c|}{ Timeliness } & \multirow[t]{2}{*}{ Conclusions } \\
\hline & Handheld Computers & Paper and Pencil & \\
\hline Rivellese AA et al.1991 40 & $\begin{array}{l}\text { I minutes/week to transfer data } \\
\text { into computer with 'Food-Meter' } \\
\text { cable hook up. }\end{array}$ & $\begin{array}{l}>30 \text { minutes/week with } \\
\text { conventional method. Specific data } \\
\text { not provided. }\end{array}$ & No conclusions were made \\
\hline Tiplady B et al. 199738 & $\begin{array}{l}\text { Authors claim electronic diary } \\
\text { automation reduced total data } \\
\text { handling time by over } 80 \% \text {; specific } \\
\text { data not provided. }\end{array}$ & Specific data not provided & No conclusions were made \\
\hline Lal SO et al. 200035 & $\begin{array}{l}\text { Average PDA data collection and } \\
\text { hook up time was } 50 \text { minutes for } \\
\text { every group of } 10 \text { patients entered }\end{array}$ & $\begin{array}{l}\text { Manual collection with computer } \\
\text { entry method was } 65 \text { minutes for } \\
\text { each group of } 10 \text { patients. Total } \\
\text { time decreased by } 23 \%\end{array}$ & $\begin{array}{l}\text { Handheld computers decreased } \\
\text { total time by } 23 \%\end{array}$ \\
\hline Walker I et al. $2004{ }^{32}$ & $\begin{array}{l}0.25 \text { days from intravenous } \\
\text { infusion to receipt of data. } \\
\text { Reminder phone calls I/patient }\end{array}$ & $\begin{array}{l}25 \text { days from intravenous infusion } \\
\text { to receipt of data. } \\
\text { Reminder phone calls 5/patient }\end{array}$ & $\begin{array}{l}\text { Major statistical and clinical } \\
\text { significance. }\end{array}$ \\
\hline
\end{tabular}




\section{Patient preference}

Table 4 provides a summary of the data related to patient preferences. Four of the nine RCTs evaluated patient preference as a secondary outcome measure, using patient surveys [32,37-39] while ten of the twenty-two patients in a fourth study who had been randomized to handheld computers but who had previously used paper diaries took part in a subsequently published qualitative study [41]. Three out of four trials found that subjects preferred portable handheld devices to paper and pencil $[32,38,39]$, while in the fourth study a small majority of subjects preferred a paper and pencil questionnaire [37]. In total, 54/ 91 (59\%) of subjects favored the used of the PDA, 17/91 subjects (19\%) favored paper methods of data capture. Twenty out of 91 subjects, (22\%) indicated "no preference".

\section{Discussion}

Despite the numerous investigations describing the potential advantages that hand-held computers offer in research and health care settings compared to traditional paper data collection methods $[2,4,6,8,9,15,16,42,43]$ only a handful of these studies adhered to the ideal, experimental method for the evaluation of effectiveness - the RCT (Randomized Controlled Trial)[44]. However, we were able to identify nine studies that comparatively evaluated handheld computers and pencil and paper methods using an RCT crossover or parallel design. The results of this review suggest that handheld computers have the potential not only to overcome some of the limitations of conventional paper and pencil devices but to supersede them, particularly with respect to improving timeliness of data handling. In addition, the preference by research subjects for handheld computers could result in improved adherence to data collection protocols for long-term studies, as evidenced by the markedly improved adherence and patient preference for the handheld computer group in the study having the longest observation period [32].

The importance of data quality from investigator's and sponsors' perspectives has been highlighted elsewhere as the most important issue in considering new data capture technologies [45]. On the other hand an increased accu- racy of data entry cannot be assumed for either method. In this review only two of the six studies found handheld computers to be more accurate, in three studies accuracy was similar and in one study the paper method was more accurate. Data entry with handheld computers can in some cases be made relatively foolproof by carefully structuring the questions to allow only determinate types of responses and by the use of prompts to ensure that questions are followed in sequence and cannot be skipped. However, handheld computers will not result in greater accuracy of data where the performance of the paper method is already at a high level or where the source of error is in data collection rather than in data entry or transmission.

Recently, the utility and validity of paper and pencil diaries has been called into question by the findings of Stone et al's [46] suggesting high levels of faked compliance in paper diaries. The same study also demonstrates the capacity of handheld computers to improve and provide objective measures of adherence to protocols by time and date stamping data entries [47]. The authors of one study in this review made similar speculations about retrospective data entry after finding high rates of missing data using handheld computers (designed not to permit retrospective entry) but low rates of missing data in paper diaries [38]. Despite Stone et al's invention and validation of a paper diary equipped with a photo sensor and capable of detecting opening and closing of the diary [47] only one of the studies in this review evaluated direct comparisons of adherence between methods[32]. This latter study evaluated adherence to a set schedule for data transmission rather than evaluating adherence to timely data entry. Future research should be directed towards the endeavor of making direct comparisons of adherence between methods as part of the larger project of validating handhelds for data capture among patient populations.

Differences between the handheld and paper and pencil instruments in data entry, in data handling and transfer times, were seldom evaluated in these studies, yet, theoretically handheld computers offer enormous temporal and financial benefits that deserve further exploration in

Table 4: Summary of RCTs assessing patient preference

\begin{tabular}{lccc}
\hline \multicolumn{1}{c}{ Study (Author, Year) } & & Proportion of Patients with a Preference (\# [\%]) & No Preference \\
\cline { 2 - 4 } & PDA & Paper & $14 / 46(30)$ \\
\hline Drummond HE et al., 1995 39 & $26 / 46(57)$ & $6 / 46(13)$ & $5 / 22(23)$ \\
Tiplady B et al., 1997 38 & $13 / 22(59)$ & $4 / 22(18)$ & $1 / 13(8)$ \\
Stratton RJ et al., 1998 37 & $5 / 13(38)$ & $7 / 13(54)$ & $0 / 10(0)$ \\
Walker I et al.,2004 & $10 / 10(100)$ & $0 / 10(0)$ & \\
Arnold E et al., 2005 32 & & & \\
(Follow-up qualitative study) & & &
\end{tabular}


clinical research. Typically in research vast quantities of data must be collected, organized, and transcribed by key entry into a file using computer software. Often this is done twice (double-data entry) to ensure accuracy and reduce the potential for human error. Using a handheld computer for data collection can eliminate these processes, which are costly and time consuming, resulting in a superior method to conventional paper and pencil devices.

As care and treatment strategies become increasingly patient centered, patient preferences are taken into greater consideration. Preference is defined as the level of desirability that a person associates with a particular health state, treatment process or level of participation [48]. Accordingly, 4 of the 9 studies summarized in this review evaluated patient preferences for either electronic or paper and pencil data capture at the end of the studies. In three out of four of these studies a larger percentage of patients preferred handheld computers to paper and pencil for data capture (Table 4). These findings are important because research has shown that patient satisfaction can influence the efficacy of interventions and levels of compliance [48]; therefore it seems in the interests of the investigator to consider and incorporate patient preferences when choosing a data collection tool. A recent study from our centre has also shown that method of record keeping is an important factor contributing to adherence of reporting [41].

The analysis of these studies provides evidence that handheld computer devices are an effective technology for data collection in the health care setting and in health related research. When compared to paper and pencil methods of data recording the handheld computers appear to be faster and preferred by most patients. The accuracy of the data collected may be greater with handheld computers in some circumstances but not all and the definitions of accuracy varied between studies. Future studies in this area would benefit from a more standardized definition of accuracy to allow for inter-study comparisons of results. As well, additional information to assess adherence to data collection requirements would also be useful as part of the overall assessment of the usefulness of handheld computer technology for data collection in the health care setting.

Recently, a number of authors have stressed the limitations of randomized trials in assessing the role of computer systems, indicating that questions such as how and why computer systems are used and explanations of various phenomena are best answered by studies based on qualitative, technical, psychological and other methods [49-51]. None of these authors are however suggesting that randomized trials be abandoned, and in fact are sug- gesting an integrated approach involving both quantitative and qualitative methods. Our opinion is that the randomized trial is best suited for comparing the ultimate performance of two or more methods in their actual clinical settings. Questions of generalizability to situations outside the actual test conditions will arise, but this is well understood. We suggest that the emphasis, though not the only role, of other methods is in the explanation of observed phenomena and in the actual development of systems. In deciding on a method of data collection, researchers could reasonably consider that handheld computers will likely be acceptable to patients and have the potential to provide more rapid data handling. On the other hand, improved compliance and accuracy of data recording should not be assumed and may depend on the particular conditions of the study, the origin of these aspects may lie outside the nature of the recording device, such as in training, understanding and motivation.

\section{Conclusion}

These studies illustrate many of the technical qualities of handheld computers described in previous reviews and are highlighted by their direct comparison with those of the paper standard when these methods are used side by side. Handheld computers can be programmed to provide determinate responses, date stamped to document times of data entry, restrict times of data entry, prevent retroactive data entry, limit 'look back' to previous data, prevent omissions of data entry, and can save considerable time and labor incurred in data handling. Handheld computers are well accepted, and are more likely than paper methods to be the choice of the user. The ultimate results with handheld computers have in most trials been similar to those of the paper method, particularly when the performance of the paper method is already high, and therefore improved accuracy cannot be assumed. The potential advantages of handheld computers lie in their technical advantages which should be carefully considered when designing the software programs to match the task.

\section{Competing interests}

The author(s) declare that they have no competing interests.

\section{Authors' contributions}

SL carried out the research and took the lead role in preparing the manuscript; $\mathrm{NH}$ was the academic supervisor of $\mathrm{SL}$, assessed the accuracy of the search, reviewed the selected articles and provided major editing of the manuscript; EA provided SL with assistance in defining search criteria and methodology, and reviewed the manuscript and many of the articles; IW conceived the study, independently selected the articles and provided major editing. All authors provided approval to thesubmitted manuscript. 


\section{Acknowledgements}

We are grateful to Jeanette Button for providing administrative support on this manuscript. This study was funded by McMaster University and Canadian Blood Services (Kenneth J. Fyke Award).

\section{References}

I. van Gerven JM, Schoemaker RC, Jacobs LD, Reints A, MJ OM, Hoedemaker HG, Cohen AF: Self-medication of a single headache episode with ketoprofen, ibuprofen or placebo, homemonitored with an electronic patient diary. Br J Clin Pharmacol 1996, 42:475-48I.

2. Jamison RN, Raymond SA, Levine JG, Slawsby EA, Nedeljkovic SS, Katz NP: Electronic diaries for monitoring chronic pain: Iyear validation study. Pain 200I, 91 1:277-285

3. Scharer LO, Hartweg V, Hoern M, Graesslin Y, Strobl N, Frey S, Biedermann C, Walser S, Walden J: Electronic diary for bipolar patients. Neuropsychobiology 2002, 46 Suppl I: I0-12.

4. Hyland ME, Kenyon CA, Allen R, Howarth P: Diary keeping in asthma: comparison of written and electronic methods. $B M$ 1993, 306:487-489.

5. Caro JJS, Caro I, Caro J, Wouters F, Juniper EF: Does electronic implementation of questionnaires used in asthma alter responses compared to paper implementation? Qual Life Res 2001, I0:683-691.

6. Gupta PC: Survey of sociodemographic characteristics of tobacco use among $\mathbf{9 9 , 5 9 8}$ individuals in Bombay, India using handheld computers. Tob Control 1996, 5: I |4- I 20.

7. Saleh KJ, Radosevich DM, Kassim RA, Moussa M, Dykes D, Bottolfson $H$, Gioe TJ, Robinson H: Comparison of commonly used orthopaedic outcome measures using palm-top computers and paper surveys. J Orthop Res 2002, 20: I|46-II5I.

8. Rabin JM, McNett J, Badlani GH: A computerized voiding diary. J Reprod Med 1996, 41:80I-806.

9. Rabin JM, McNett J, Badlani GH: "Compu-Void II": the computerized voiding diary. J Med Syst 1996, 20:19-34.

10. Shiffman S, Hufford M, Hickcox M, Paty JA, Gnys M, Kassel JD: Remember that? A comparison of real-time versus retrospective recall of smoking lapses. J Consult Clin Psychol 1997 65:292-300.

II. Shiffman S, Elash CA, Paton SM, Gwaltney CJ, Paty JA, Clark DB, Liu KS, Di Marino ME: Comparative efficacy of 24-hour and 16 hour transdermal nicotine patches for relief of morning craving. Addiction 2000, 95: I I85- I I95.

12. Wright P, Rogers N, Hall C, Wilson B, Evans J, Emslie H, Bartram C: Comparison of pocket-computer memory aids for people with brain injury. Brain Inj 200I, I 5:787-800.

13. Wright P, Rogers N, Hall C, Wilson B, Evans J, Emslie H: Enhancing an appointment diary on a pocket computer for use by people after brain injury. Int J Rehabil Res 200I, 24:299-308.

14. Johannes CB, Crawford SL, Woods J, Goldstein RB, Tran D, Mehrotra S, Johnson KB, Santoro N: An electronic menstrual cycle calendar: comparison of data quality with a paper version. Menopause 2000, 7:200-208.

15. Selanikio JD, Kemmer TM, Bovill M, Geisler K: Mobile computing in the humanitarian assistance setting: an introduction and some first steps. J Med Syst 2002, 26: I 13-125.

16. Fletcher LA, Erickson DJ, Toomey TL, Wagenaar AC: Handheld computers. A feasible alternative to paper forms for field data collection. Eval Rev 2003, 27: 165-178.

17. Clarke WL, Cox DJ, Gonder-Frederick LA, Kovatchev B: Hypoglycemia and the decision to drive a motor vehicle by persons with diabetes. JAMA 1999, 282:750-754.

18. Wegner KE, Smyth JM, Crosby RD, Wittrock D, Wonderlich SA Mitchell JE: An evaluation of the relationship between mood and binge eating in the natural environment using ecological momentary assessment. Int J Eat Disord 2002, 32:352-36I.

19. Iregui $M$, Ward S, Clinikscale D, Clayton D, Kollef MH: Use of a handheld computer by respiratory care practitioners to improve the efficiency of weaning patients from mechanical ventilation. Crit Care Med 2002, 30:2038-2043.

20. Sellors JW, Hayward R, Swanson G, Ali A, Haynes RB, Bourque R, Moore KA, Lohfeld L, Dalby D, Howard M: Comparison of deferral rates using a computerized versus written blood donor questionnaire: a randomized, cross-over study [ISRCTN84429599] 25. BMC Public Health 2002, 2: I4.
21. Henker B, Whalen CK, Jamner LD, Delfino RJ: Anxiety, affect, and activity in teenagers: monitoring daily life with electronic diaries. J Am Acad Child Adolesc Psychiatry 2002, 4 I :660-670.

22. Fischer S, Stewart TE, Mehta S, Wax R, Lapinsky SE: Handheld computing in medicine. J Am Med Inform Assoc 2003, I 0:139-149.

23. Miller SM, Beattie MM, Butt AA: Personal digital assistant infectious diseases applications for health care professionals. Clin Infect Dis 2003, 36:1018-1029.

24. MM W, R S, C H, WP M, JL W: Clinical documentation: the handheld computer as a survival tool. MD Computing 1998 , I 5:356-358

25. W G, A H, Gillies: Hand-held computers in healthcare: what software programs are available? New Zealand Medical Journal 2002, I I 5:Ul80.

26. Keplar KE, Urbanski Cl: Personal digital assistant applications for the healthcare provider. Ann Pharmacother 2003, 37:287-296.

27. Lehman K: Clinical nursing instructors' use of handheld computers for student recordkeeping and evaluation. J Nurs Educ 2003, 42:4l-42.

28. Usatine R: Teaching and practicing medicine with handheld computers. Fam Med 2002, 34:719-720.

29. Adatia F, Bedard PL: "Palm reading": 2 . Handheld software for physicians. CMA/ 2003, 168:727-734

30. Koop A, Mosges R: The use of handheld computers in clinical trials. Control Clin Trials 2002, 23:469-480.

31. DL S, GR N: PDQ Epidemiology 2nd edition edition. St Louis, MosbyYear Book Inc.; 1996:48-78.

32. Walker I, Sigouin C, Sek J, Almonte T, Carruthers J, Chan A, Pai M, Heddle N: Comparing hand-held computers and paper diaries for haemophilia home therapy: a randomized trial. Haemophilia 2004, 10:698-704

33. Quinn P, Goka J, Richardson H: Assessment of an electronic daily diary in patients with overactive bladder. BJU Int 2003, 91:647-652.

34. Jamison RN, Gracely RH, Raymond SA, Levine JG, Marino B, Herrmann TJ, Daly M, Fram D, Katz NP: Comparative study of electronic vs. paper VAS ratings: a randomized, crossover trial using healthy volunteers. Pain 2002, 99:341-347.

35. Lal SO, Smith FW, Davis JP, Castro HY, Smith DW, Chinkes DL, Barrow RE: Palm computer demonstrates a fast and accurate means of burn data collection. J Burn Care Rehabil 2000, 21:559-56I.

36. McBride JS, Anderson RT, Bahnson JL: Using a hand-held computer to collect data in an orthopedic outpatient clinic: a randomized trial of two survey methods. Med Care 1999, 37:647-65I

37. Stratton RJ, Stubbs RJ, Hughes D, King N, Blundell JE, Elia M: Comparison of the traditional paper visual analogue scale questionnaire with an Apple Newton electronic appetite rating system (EARS) in free living subjects feeding ad libitum. Eur J Clin Nutr 1998, 52:737-74|

38. B T, GK C, MH D, FGE B, SP M, LM CA, D. B: The use of Electronic Diaries in Respiratory Studies. Drug Information Journal 1997, 31:759-764.

39. Drummond HE, Ghosh S, Ferguson A, Brackenridge D, Tiplady B: Electronic quality of life questionnaires: a comparison of pen-based electronic questionnaires with conventional paper in a gastrointestinal study. Qual Life Res 1995, 4:21-26.

40. Rivellese AA, Ventura MM, Vespasiani G, Bruni M, Moriconi V, Pacion D, Sulpini MT, Borrelli R, Giacco A, Cangemi C, .: Evaluation of new computerized method for recording 7-day food intake in IDDM patients. Diabetes Care 1991, 14:602-604.

4I. Arnold E, Heddle N, Lane S, Sek J, Almonte T, Walker I: Handheld computers and paper diaries for documenting the use of factor concentrates used in haemophilia home therapy: a qualitative study. Haemophilia 2005, I I:2 I6-226.

42. Christiansen DH, Hosking JD, Dannenberg AL, Williams OD: Computer-assisted data collection in multicenter epidemiologic research. The Atherosclerosis Risk in Communities Study. Control Clin Trials 1990, I I:I01-II5.

43. Robinson D: Data capture using hand-held computers. J Psychiatr Ment Health Nurs 1994, I: 126- I 27.

44. A B: Health needs and their assessment: demography and epidemiology. Research Methods in Health: Investigating Health and Health Services 1997:6I [http://www.mcgraw-hill.co.uk/openupusa/ html/0335206433.html] 
45. A L, JW, .: Data capture from the sponsors' and investigator's perspective: Balancing quality, speed, and cost. Drug Information Journal I998, 32:87I-886.

46. Stone AA, Shiffman S, Schwartz JE, Broderick JE, Hufford MR: Patient non-compliance with paper diaries. BMJ 2002, 324: I I93-I 194.

47. Stone AA, Shiffman S, Schwartz JE, Broderick JE, Hufford MR: Patient compliance with paper and electronic diaries. Control Clin Trials 2003, 24: 182-199.

48. Ricard N, Kind P, Christian S, Jensen M, Stewart J: Link between patient preferences and treatment outcomes in seasonal allergic rhinitis: an empiric investigation. Clin Ther 1999, 21:268-277.

49. Kaplan B: Evaluating informatics applications--some alternative approaches: theory, social interactionism, and call for methodological pluralism. Int J Med Inform 200I, 64:39-56.

50. A S: Integrating quantitative and qualitative methods in patient care information system evaluation: guidance for the organizational decision maker. Methods Inf Med 2003, 32: $141-150$.

51. Kushniruk A: Evaluation in the design of health information systems: application of approaches emerging from usability engineering. Comput Biol Med 2002, 32:141-149.

\section{Pre-publication history}

The pre-publication history for this paper can be accessed here:

http://www.biomedcentral.com/1472-6947/6/23/prepub

Publish with Bio Med Central and every scientist can read your work free of charge

"BioMed Central will be the most significant development for disseminating the results of biomedical research in our lifetime. "

Sir Paul Nurse, Cancer Research UK

Your research papers will be:

- available free of charge to the entire biomedical community

- peer reviewed and published immediately upon acceptance

- cited in PubMed and archived on PubMed Central

- yours - you keep the copyright 